\title{
repisälud
}

This is the peer reviewed version of the following article:

Gomez-Gaviro MV, Lovell-Badge R, Fernandez-Aviles F, Lara-Pezzi E. The Vascular Stem Cell Niche. J Cardiovasc Transl Res. 2012;5(5):618-30

which has been published in final form at: https://doi.org/10.1007/s12265-012-9371-x 


\section{The vascular stem cell niche}

Authors: Maria Victoria Gómez-Gaviro ${ }^{1,2 *}$, Robin Lovell-Badge ${ }^{3}$, Francisco Fernández-Avilés ${ }^{1,2}$ and Enrique Lara-Pezzi ${ }^{4}$.

Affiliations: ${ }^{1}$ Servicio de Cardiología and ${ }^{2}$ Instituto de Investigación Sanitaria Gregorio Marañón, Hospital General Universitario Gregorio Marañón, Doctor Esquerdo 46, 28007 Madrid, Spain; ${ }^{3}$ Division of Stem Cell Biology and Developmental Genetics, National Institute for Medical Research, MRC, The Ridgeway, Mill Hill, NW7 1AA, London, UK; ${ }^{4}$ Cardiovascular Development and Repair Dept., Centro Nacional de Investigaciones Cardiovasculares, Melchor Fernández Almagro 3, 28029 Madrid, Spain.

*Correspondance: Maria Victoria Gómez-Gaviro, Servicio de Cardiología, Hospital General Universitario Gregorio Marañón, Doctor Esquerdo 47, 28007 Madrid, Spain. E-mail: vgomez@recava.com 


\begin{abstract}
Stem cells in adult organs reside in specialised niches that regulate their proliferation and differentiation. Investigations during the last few years have unveiled a regulatory role for blood vessels in these microenvironments. Mesenchymal stem cells are located surrounding capillaries in a variety of tissues and have the capacity to differentiate into different mesodermal lineages. Angiogenic progenitor cells have also been found in the adventitial layer of large vessels. In the bone marrow, endothelial cells control hematopoietic stem cell release and in the brain blood vessels regulate neural stem cell self-renewal and neurogenesis. Similarly, perivascular progenitor cells have also been found in the heart. This intimate connection between stem cells and the vasculature contributes to tissue homeostasis and repair. In this review we focus on the regulation of stem and progenitor cells in different adult niches by blood vessels and the few mechanisms that are known to mediate this interaction.
\end{abstract}

Keywords: stem cell niche, perivascular, pericyte, cytokine, growth factor 
For centuries blood vessels have been defined as conduits that distribute oxygen and nutrients to all tissues in the body. Recently however, the vasculature has been suggested to play a role in tissue homeostasis and repair that goes beyond its traditional blood carrier function and involves hosting and regulation of stem and progenitor cells. Adult stem cells reside in specialized niches that provide an ideal microenvironment for the maintenance of their properties (Fig. 1). In these niches, stem cells are often found in the proximity of blood vessels, suggesting a role for the niche vasculature in supporting stem cell function [1-5]. However the precise role of blood vessels in the regulation of stem cell self-renewal and differentiation and the contribution of the perivascular niche to tissue homeostasis and repair is far from being well understood. Here we summarize recent advances in our knowledge of the vascular stem cell niche in adult mammalian organisms.

\section{Pericytes and Mesenchymal Stem Cells}

Throughout the body different types of progenitor cells accumulate around blood vessels. Capillaries, arterioles and venules are covered by pericytes in a discontinuous manner at a ratio of 1-10 endothelial cells for each pericyte, depending on the tissue [6]. Pericytes are located within the basement membrane and in direct contact with endothelial cells. They are distributed along microvessels and don't seem to occupy a particular microenvironment in the tissue. Although their exact function is not completely understood, they're thought to regulate endothelial cell proliferation, permeability and integrity. Because there is no unique marker for pericytes, these cells are defined by their ultrastructural characteristics and by the expression, among other markers, of the proteoglycan NG2 and the receptor for platelet-derived growth factor $\beta$ (PDGF- $\beta$ ) [6]. PDGF- $\beta$ is one the main mediators of endothelium-pericyte communication. It is necessary for pericyte recruitment by endothelial cells not only during development but also in disease. Blockade of PDGF- $\beta$ after myocardial infarction impairs pericyte recruitment by capillaries in the injured area, prevents vessel maturation, prolongs inflammation and interferes with extracellular matrix deposition in the infarct region [7]. 
Similarly, PDGF- $\beta$ mediates the recruitment of pericytes from the epicardium to cover new vessels in the regenerating zebrafish heart [8].

In addition to their supportive role for endothelial cells, pericytes have been suggested to contribute to tissue homeostasis as progenitor cells [9]. Pericytes from different organs can differentiate into a variety of mesoderm-derived cell types, such as osteoblasts, skeletal myocytes, SMCs, adipocytes and others $[6,9,10]$. This plasticity has led to the suggestion that pericytes are mesenchymal stem cells (MSCs) [9]. Although both cell types share some markers and differentiation potential, whether they actually represent the same cell type, whether MSCs represent a pericyte subpopulation or whether they can give rise to each other is currently under debate $[6,11,12]$.

MSCs were originally described in the bone marrow stroma as fibroblast-like cells (colony-forming unit fibroblast, CFU-F) with the capacity to acquire osteoblast, chondrocyte and adipocyte phenotypes [12,13]. Bone marrow MSCs (BM-MSCs) were subsequently identified in other organs and the term MSCs was generalized to refer to stem cells with a mesenchymal phenotype that can differentiate into a number of mesodermal tissues, including muscle, fat and bone. The perivascular location of MSCs was noted initially in the bone marrow and then confirmed in other tissues [14]. Unfortunately, the lack of a unique MSC marker has obfuscated the investigation of the origin and true differentiation potential of these cells. Although MSCs are often referred to as a single cell type, it is likely that it comprises a heterogeneous population of cells with diverse differentiation potential [12]. The intermediate filament Nestin has recently been shown to be a reliable BM-MSC marker [15], but it remains to be seen whether MSCs from other tissues can be discriminated using this protein, which also marks other mesenchymal tissues and neural progenitors.

One of the most attractive features of MSCs is their ability to differentiate into a range of cell types regardless of their tissue of origin [9,11]. The ease of isolation of MSCs together with their plasticity makes them ideal for regenerative therapies for diverse organs, including the infarcted heart. Initial studies showed that injection of bone marrow cells after myocardial infarction, including MSCs but only a few hematopoietic cells, improve cardiac function [16,17]. 
Recent clinical trials with purified bone marrow-derived MSCs have proven the safety of the treatment, showing functional improvement and reduced remodelling in some patients [18-20]. The exact cellular contribution of MSCs to the heart - if any - is difficult to determine accurately, mainly due to the lack of specific markers. Only a small proportion of the injected MSCs has been reported to transdifferentiate into cardiomyocytes or endothelial cells [21,22] and it is now generally accepted that they provide beneficial effects mainly through paracrine mechanisms [20]. Besides secreting growth factors and extracellular matrix remodelling proteins, MSCs, at least those isolated from the bone marrow, have anti-inflammatory properties that contribute to their therapeutic potential [23]. Modulation of inflammation may be partially responsible for the beneficial effects observed after MSC injection into injured tissues, which would allow activation of endogenous repair mechanisms. As discussed below, perivascular MSCs are not only thought to be regulated by blood vessels in the stem cell niche but they also play a regulatory role themselves.

\section{The adventitial niche}

The traditional view of the tunica adventitia as a passive layer with a mere support role has been challenged in recent years [24]. The adventitia controls the exchange of endothelial and SMCs with the surrounding tissue and the formation of vessels that nourish these two layers [24]. It also regulates the remodelling of the vessel wall, smooth muscle contraction and hosts a number of leukocyte populations ready to fight a possible infection. Interestingly, a number of progenitor cell populations have been identified in this layer that argues for a niche role of the adventitia of large vessels $[11,24,25]$. These cells are different from pericytes and MSCs but can differentiate into the latter in vitro [11]. They mainly give rise to endothelial or smooth muscle cells and participate in angiogenesis. Both $\mathrm{CD}^{+} 4^{+}$and $\mathrm{CD} 34^{-}$progenitor cells with vasculogenic capacity have been described in the adventitia [26-28]. Some of these can give rise to multipotent cells in vitro that resemble MSCs derived from microvessels, arguing for a common MSC origin [29]. $\mathrm{CD} 4^{+} / \mathrm{CD} 133^{+} / \mathrm{VEGFR}^{+}$cells in the human fetal aorta can generate both endothelial and mural cells [30]. A similar $\mathrm{CD}^{+} 4^{+}$progenitor population was identified in the vasa vasorum of the 
saphenous vein that promotes angiogenesis and revascularization by secreting angiogenic factors. These $\mathrm{CD} 4^{+} / \mathrm{SOX}^{+} / \mathrm{CD} 31^{-}$cells, which include a subpopulation of $\mathrm{NG}^{+} / \mathrm{PDGFR}^{+}$ MSCs, are clonogenic and can be induced to differentiate into different mesodermal phenotypes [31]. Injection of these cells into the infarcted heart reduces remodelling and improves cardiac function [32]. Cells maintain their original phenotype after engraftment into the damaged heart and activate an endogenous angiogenic response by secreting miR-132 and growth factors. Whether the microvessels of the vasa vasorum constitute a vascular stem/progenitor cell niche is an intriguing possibility that deserves further study [24].

Progenitor cells in the adventitia can also contribute to vascular disease. A population of perivascular $\mathrm{SCA}^{+} / \mathrm{CD}^{+} 4^{+} / \mathrm{c}-\mathrm{KIT}^{-} / \mathrm{CD} 140 \mathrm{~b}^{+}$cells appear in the aorta and other large vessels during embryonic development in response to sonic hedgehog (Shh) signalling [33]. These cells can differentiate into SMC-like cells and contribute to embryonic and postnatal growth of the vascular wall. In addition, they also play a role in pathological vascular remodelling in ApoE knockout mice, in which these cells are very abundant. In this model, $\mathrm{SCA}^{+}$cells transdifferentiate into SMCs in response to PDGF- $\beta$ and contribute to atherosclerosis [34]. In addition, a population of $\mathrm{SCA} 1^{+} / \mathrm{CD} 45^{+}$cells has been recently identified in the adventitia of the aorta [35]. These rare cells have hematopoietic potential and mainly give rise to monocytes and macrophages, thus representing a source of inflammatory cells. Finally, a role for adventitial $\mathrm{SCA}^{+}$cells in tumor formation has also been suggested [24].

\section{Hematopoietic Stem Cells}

Hematopoietic and endothelial cells are intimately associated from the embryo to adulthood [36,37]. The ability of blood vessels to supply stem cells is evolutionarily conserved from fish to mammals and may be reminiscent of embryonic development, during which haemogenic endothelial cells emerge from the dorsal aorta and differentiate into hematopoietic cells [38-40]. In the adult bone marrow, two types of niche - osteoblastic and vascular - support stem cell function $[1,41]$. Whereas the osteoblasts in the endosteum (the inner part of the bone) support hematopoietic stem cell (HSC) quiescence by secreting angiopoietin-1, the vascular niche 
promotes proliferation, differentiation and migration of HSCs by providing higher concentrations of oxygen, nutrients and growth factors [1,41,42]. It is estimated that around $60 \%$ of HSCs are located around blood vessels in the bone marrow, although this figure may underestimate the number of HSC in contact with endosteal blood vessels [43,44]. In addition, perivascular hematopoietic niches have been described in other organs like the spleen $[43,44]$ and a recent report showed that HSCs are generated around blood vessels in the placenta during development [45]. These reports suggest that the vasculature provides signals that regulate stem cell behaviour. The study of this communication was first addressed in vitro. Co-culture of progenitor cells with endothelial cells increased their capacity to repopulate the bone marrow of SCID mice [46]. Interestingly, exposure of HSCs to endothelial cells isolated from different tissues resulted in varying HSC growth and repopulating ability [47].

Although the bone marrow was one of the first niches described, the molecular mechanisms by which stem cells interact with their microenvironment are still not completely understood. Both paracrine effects and direct cell-cell contact have been implicated in the HSCendothelium communication. Endothelial cells express the Notch ligands Jagged and Delta-like that support long-term HSC proliferation and prevent their exhaustion [48]. Notch expression in HSCs is dependent on Wnt signalling and is necessary for maintenance of an undifferentiated state [49]. In addition, Notch-independent Wnt signalling is necessary for HSC growth and for their regenerative capacity [50]. Following injury, Notch promotes proliferation of short- and long-term progenitors and delays myeloid differentiation, although it seems to play no role once homeostasis is reached [51]. Notch signals have also been shown to be activated by ligands in osteoblastic cells [52]. These cells also interact with HSCs through N-cadherin, although the relevance of this interaction is controversial $[53,54]$. The endothelium also promotes HSC selfrenewal and differentiation through paracrine mechanisms. Activation of the Akt signalling pathway in endothelial cells induces the release of soluble factors like FGF2 and IGFBP2 that enhance HSC long-term proliferation and self-renewal. In contrast, activation of the Erk pathway induces different growth factors that shift the response of HSCs towards differentiation. These results suggest that signalling changes within the endothelial cell have a direct impact on the 
HSC niche [55]. In this regard, endothelial cells from diabetic mice show functional alterations associated with reduced vascular perfusion and HSC depletion in the bone marrow [56].

The regulation of HSC in the bone marrow is strongly supported not just by the endothelium but also by perivascular MSCs. In fact, transplantation of perivascular MSCs can reconstitute the HSC microenvironment in a heterotopic site outside the bone marrow [57]. HSCs and progenitor cells are attracted to the vascular niche by SDF-1/CXCL12 through its receptor CXCR4 [58]. SDF-1 is produced by the endothelium and by CXCL12-abundant reticular cells (CARs), which are located around endothelial cells and help maintain HSC quiescence [58-60]. CAR cells are also found in the endosteum, suggesting that both HSC niches act interdependently and can not be separated. SDF-1 is also secreted by a population of perivascular Nestin $^{+}$MSCs associated with HSCs in the bone marrow parenchyma and next to the bone [15]. These cells are in close association with catecholaminergic nerve fibres and produce high amounts of SDF-1 and angiopioetin-1. Expression of these HSC homing factors in Nestin ${ }^{+}$MSCs is downregulated by both G-CSF and $\beta 3$ adrenergic receptor ligands to allow HSC mobilization. SDF-1 downregulation in MSCs and subsequent HSC egression from the bone marrow is impaired in diabetic patients and animal models of diabetes. Defective HSC mobilization by GCSF can be rescued by inhibition of the SDF-1/CXCR4 interaction, which may have important implications for diabetic patients needing autologous HSC transplantation [61]. Whether CAR and Nestin ${ }^{+}$MSCs represent the same population is still unclear, but SDF-1-producing cells seem to be connected through connexin gap junctions that help collectively coordinate SDF-1 production in the bone marrow [62]. Together with FGF4, SDF-1 also recruits megakaryocytic progenitors to the vascular niche to promote cell survival and platelet maturation [63]. It is important to note that SDF-1 expression in the HSC niche depends on the presence of macrophages. Mobilization of these cells from the bone marrow results in defective SDF-1 production by MSCs and indirectly induces HSC egression [64,65]. Interestingly, it has been recently reported that stem cell factor $(\mathrm{SCF} / \mathrm{KITL})$ is expressed by endothelial cells and perivascular MSCs in the niche. Deletion of the Scf gene specifically in these cells - but not in HSCs, osteoblasts or hematopoietic cells - results in HSC depletion in the bone marrow, suggesting that SCF is an essential component of the vascular stem cell niche in this tissue [66]. 


\section{Neural Stem Cells}

Neural stem cells (NSCs) have the potential to generate the three main cell types that form the central nervous system (CNS), neurons, astrocytes and oligodendrocytes [67,68]. Although there are no unique markers for NSCs, these cells are characterised by being SOX2 ${ }^{\text {hi }}, \mathrm{Nestin}^{+}, \mathrm{GFAP}^{+}$, Glast $^{+}$and Mash1 ${ }^{-}$. During each cell division, stem cells can divide symmetrically, giving rise to two identical stem cells, or undergo an asymmetric division, generating a stem cell and a cell committed to differentiate, either directly or after proliferation. The decision of an NSC to undergo one or another type of division is made in response to external cues provided by the cell's environment. NSCs, as with other adult stem cells, reside in a specialized microenvironment known as a stem cell niche [69]. Two main NSC niches have been described in the adult mouse brain: the subventricular zone (SVZ) and the dentate gyrus in the hippocampus (DG) $[68,69]$. Located on the lateral wall of the lateral ventricles, the SVZ is composed of different cell populations, including a monolayer of ependymal cells that lines the ventricle, NSCs, transit-amplifying cells, neural progenitors (neuroblasts), astrocytes and a dense network of blood vessels.

In the adult mammalian brain, NSCs are located close to the vasculature in the different NSC niches [70] (Fig. 2). In the DG of the hippocampus, clusters of proliferating cells are associated with blood vessels, suggesting a link between neurogenesis and angiogenesis [71]. In the SVZ, which is densely vascularized, neurogenesis is also associated with the vasculature $[72,73]$. Most proliferating cells are found adjacent or very close to the blood vessels although, in contrast with the DG, no proliferation of endothelial cells is observed in the SVZ [72,73]. GFAP stem cell astrocytes and transit-amplifying progenitor cells are located in the proximity of the capillaries and chains of neuroblasts line along the vessels as they migrate towards the rostral migratory stream (RMS), although without direct contact [72,73]. Depletion of proliferating cells in the SVZ using the antimitotic drug AraC is followed by stem cell proliferation around the blood vessels and regeneration of the SVZ niche [72]. Like HSCs, neural progenitor cells are recruited to niche blood vessels by SDF-1 and depend on $\alpha 6 \beta 1$ integrin to interact with them 
[73,74]. Blockade of this laminin receptor results in altered SVZ cell proliferation and localization [73].

The functional effect that endothelial cells exert on NSCs can be reproduced in vitro. Endothelial cells, but not smooth muscle cells, induce NSC proliferation in co-culture experiments and prevent their differentiation [75]. In addition, co-culture with endothelial cells prior to differentiation enhances the neurogenic capacity of NSCs. Although these data strongly suggest that blood vessels have an impact on stem cell function, niche homeostasis and neurogenesis, the molecular mechanisms underlying such effects are not completely understood. Interestingly, stem and progenitor cells localized around capillaries in the SVZ niche show a strong expression of the receptor for the epidermal growth factor (EGFR) that is further induced by SDF-1 [72,74], suggesting a role for the EGF family of growth factors in the regulation of NSC function in vivo. EGFR expression is further induced by pigment epithelium-derived factor (PEDF), which is secreted by endothelial and ependymal cells and supports NSC self-renewal by enhancing Notch signalling [76,77]. A role for nitric oxide (NO) in the regulation of the NSC niche has also been proposed. NO regulates both angiogenesis and neurogenesis and can promote either NSC proliferation or differentiation depending on the cellular source [70]. NO plays a role in brain tumor development [78], although its endogenous role in SVZ homeostasis needs further investigation. Aspects of the communication between endothelial cells and NSCs were recently investigated by carrying out a comprehensive analysis of the changes in gene expression that endothelial cells induce on NSCs and the soluble factors that may mediate this effect. Betacellulin (BTC), a member of the EGF family initially described to mediate the generation of $\beta$-cells in the pancreas [79], was found to induce NSC proliferation both in vitro and in vivo [80]. BTC is expressed by endothelial cells and by epithelial cells of the choroid plexus, a structure in the brain that contributes many components of the cerebral spinal fluid (CSF) present within the ventricles. Infusion of BTC leads to expansion of NSCs, transit amplifying (progenitor) cells and neuroblasts, and is both necessary and sufficient to induce regeneration of the NSC niche. Importantly, the action of BTC in the SVZ translates into increased neurogenesis both in the olfactory bulb and the dentate gyrus. 
Blood vessels also support neurogenesis beyond their effects in the niche. They provide cues that direct neuroblast migration after they leave the SVZ and secrete growth factors that promote differentiation and neurogenesis [70]. Brain-derived neurotrophic factor (BDNF) produced by the vasculature guides migration of neural progenitors and stimulates neurogenesis in SVZ explants [77,81]. Similarly, in canaries it directs migration of newly generated neurons to the high vocal centre, where it promotes neurogenesis and angiogenesis together with VEGF [82]. Together, these reports highlight the regulatory role of blood vessels in the brain and suggest therapeutic potential for some of the factors they release.

\section{Cardiac and Skeletal Muscle Stem Cells}

For years the heart was thought to be a terminally differentiated post-mitotic organ with no regenerative capacity whatsoever. The mere existence of cardiac stem cells has been under severe scrutiny over the last few years. Recent reports however have unveiled a certain degree of cardiomyocyte turnover, challenging the classical paradigm and initiating a furious debate [83,84]. It is beyond the scope of this review to settle such arguments; we will instead focus on those stem and progenitor cell populations that have been described to be localized around cardiac blood vessels. In this regard, a cell population termed cardiac colony-forming units fibroblast (cCFU-Fs) has been recently found in the heart localized in the perivascular adventitia [85]. These $\mathrm{SCA} 1^{+} / \mathrm{PDGF}-\mathrm{R}^{+} / \mathrm{CD} 31^{-}$cells are similar to MSCs found around blood vessels in the bone marrow and in many adult organs, although they do not express pericyte markers. cCFU-Fs originate in the embryonic epicardium and mainly give rise to mural components of the coronary vessels during development. Like MSCs, cCFU-Fs have clonogenic potential, they are capable of long-term growth in vitro and show broad differentiation capacity. Some of these properties are shared by mesoangioblasts, a population of $\mathrm{SCA}^{+} / \mathrm{CD} 44^{+}$cardiac progenitors that are found around blood vessels in the heart [86]. Cardiac mesoangioblasts have a narrower differentiation spectrum than cCFU-Fs and mostly give rise to cardiomyocytes. They are mainly localized around small vessels, although they can also be found in the aorta, and their number reduces with age. The cardiac vasculature also hosts a population of coronary progenitor cells. 
These VEGR ${ }^{+} / \mathrm{cKIT}^{+}$cells have the potential to generate endothelial and smooth muscle cells and contribute to vessel regeneration [87]. Unfortunately, the factors mediating the action of blood vessels on these different progenitor cells have not yet been unveiled.

In skeletal muscle, myogenic stem cells (satellite cells) are located underneath the basal lamina surrounding muscle fibres and in close proximity with capillary vessels [3]. Although satellite cells are usually quiescent, they proliferate rapidly upon injury to regenerate the damaged muscle. In culture, endothelial cells stimulate satellite cell growth by secreting a variety of growth factors, including FGF2/bFGF, HGF, IGF-1 or VEGF among others [3]. In addition, a pericyte population with myogenic potential has been found both in skeletal muscle and nonmuscle tissue [9]. These cells are characterized by the expression of mesenchymal stem cells markers and are different from satellite cells [10]. They show strong myogenic potential and contribute to muscle regeneration when injected into a mouse model of muscular dystrophy $(m d x$ mice). Interestingly, a similar capacity was recently demonstrated by endogenous pericytes from skeletal muscle using a lineage tracing system based on the expression of alkaline phosphatase [88]. Pericytes can naturally generate satellite cells, an ability mainly detected in the first month of age that is lost in the adult. Interestingly, pericyte-like cells derived in vitro from human pluripotent stem cells potentiate vascular and muscular regeneration and contribute to both tissues in a mouse model of hind limb ischemia [89]. Another stem cell population found physically associated with small capillaries in postnatal skeletal muscle are mesoangioblasts, which were originally described around the embryonic dorsal aorta [90,91]. Mesoangioblasts can be expanded in culture and have strong potential for the regeneration of skeletal muscle [90,92]. Finally, a population of myoendothelial cells was isolated from skeletal muscle [93]. These cells express some endothelial progenitor and myogenic markers and can differentiate into neural, skeletal muscle and endothelial cells. They improve skeletal muscle regeneration and show beneficial effects when injected into the heart after myocardial infarction $[93,94]$.

\section{Other Stem Cells}


The stromal vascular fraction of the white adipose tissue represents the major source of MSCs. These MSCs are easily isolated and display the same differentiation potential as MSCs isolated from other tissues [9], which makes them an attractive candidate for regenerative therapies. In this regard, injection of adipose tissue MSCs in pig infarcted hearts contributes to vessel formation and improves cardiac function with a similar efficacy to bone marrow MSCs [95]. Preliminary data from a recent clinical trial also suggest beneficial effects of adipose tissue progenitor cells in humans [96]. Interestingly, a vascular adipose stem cell niche has recently been described in white fat tissue (Fig. 3). This niche hosts MSCs and a population of $\mathrm{CD} 4^{+} / \mathrm{Sca}^{+}{ }^{+}$adipose stem cells (ASCs) that can give rise to mature adipocytes. [4,97]. ASCs are located in the mural compartment of the vessel and also express NG2, SMA and PDGFR $\beta$. The similarity between ASC and MSC markers has led to the hypothesis that ASCs actually represent a subset of MSCs. Unlike MSCs, however, ASCs mainly give rise to white fat adipocytes and not to other tissues. Interestingly, similar adipose progenitor cells have been described in the skin, where they regulate follicular stem cell activation by secreting PDGF [98]. Some adipogenic progenitors have also been reported to derive from bone marrow myeloid cells [99]. These cells generate a particular adipocyte subset and accumulate in visceral fat with age.

The existence of perivascular fat stem cells supports the proposed role of the vasculature in the growth of adipose tissue [100]. In line with these observations, angiogenesis inhibition reduces obesity and depletion of adipose vasculature results in obesity reversal [101,102]. Conversely, adipose progenitors can influence vessel formation by secreting different angiogenic factors and by enhancing the ability of endothelial progenitor cells to form new vascular networks $[100,103]$. As in other perivascular stem cell niches, it is still not completely clear how the ASC niche contributes to the mature tissue and the impact that this may have on obesity. Transplantation studies have shown that ASCs contribute to adipose tissue formation when injected into fat pads of lipodystrophic mice or mice fed with a high fat diet [97]. These cells showed no homing ability when injected intravenously and needed an adipogenic environment to form adipocytes, suggesting that the perivascular niche may provide specific cues for adipocyte differentiation. 
In the testis, a population of undifferentiated spermatogonia that includes spermatogonial stem cells is organized in niches around blood vessels, particularly at branch points where Leydig and other interstitial cells also accumulate. However, unlike stem cells in other niches, undifferentiated spermatogonia are not in direct contact with the vasculature [2]. The effect of blood vessels on spermatogonia is thought to be indirect and could be mediated by Leydig cells. These cells, whose major biological function is to produce testosterone, are adjacent to the vessel and have been described to originate from pericytes and other perivascular cells [104]. As in other organs, the factors mediating the regulation of progenitor cells by blood vessels are unclear but colony stimulating factor 1 (CSF1) has been identified in Leydig and myoid cells as a potential candidate regulating spermatogonial stem cell self-renewal [105].

\section{Artificial Stem Cell Niches as Exploratory and Therapeutic Tools}

Lessons learnt from stem cell niches in the last few years provide an opportunity for the development of novel therapeutic tools for regenerative medicine. Understanding the contribution of the different components of the niche and in particular that of blood vessels will allow us to reconstruct and use artificial vascular niches (Fig. 4). Like all biological systems, stem cell niches are extraordinarily complex and reproduction of the microenvironmental conditions in a dish represents quite a challenging task [106]. First, bioengineered niches must include a structural support in the form of matrices or hydrogels. These must not only provide a scaffold for the cells but should also allow localized dynamic delivery of different growth factors and ligands. Cytokine delivery can be manipulated in vitro through microfluidic devices but presents more of a challenge if the artificial niche is to be integrated into an organism. Second, the niche must obviously include multipotent stem cells capable of generating adult differentiated tissue and support cells that provide the necessary signals for stem cell regulation. The relative density of each cell population should also be carefully considered, as it may have a strong impact on differentiation. If necessary, cells can be micropatterned into a specific distribution in the niche. Part of these regulatory cues could be provided by blood vessels, and the use of endothelial cells or vessel-derived products in these niches is beginning to be explored 
[107,108]. Alternatively, signals from support cells could be substituted by protein-conjugated microbeads or by attaching cell surface ligands, like Jagged or Delta-like, to the scaffold surface [106]. Artificial niches must also incorporate mechanical cues that may be necessary for stem cell self-renewal and differentiation. These include for instance capillary shear stress or matrix elasticity, which can determine stem cell fate [109]. Finally, niches should be engineered in such a way that stem cells receive the right amount of oxygen, a major factor in stem cell self-renewal [110].

In addition to their regenerative potential, artificial niches can be used as biological models to study stem cell properties or individual niche components [111]. In this regard, a platform with various bioengineered microenvironments was recently designed to carry out highthroughput analysis of single stem cell differentiation [112]. This system comprises several microwells in a polyethylene glycol hydrogel, each with different proteins and extracellular matrix components that influence stem cell differentiation. The platform can also integrate physical stimuli and allows the simultaneous evaluation of a wide variety of inputs on stem cell proliferation and differentiation. A complementary approach recently developed involves the use of in vivo artificial niches. In an interesting report, Foxn1 knockout mice were used to deconstruct the thymus hematopoietic microenvironment in vivo and define the role of individual proteins in it [113]. These mice have a defective thymic epithelial niche that impairs $\mathrm{T}$ cell development. The authors used tissue-specific transgenics to overexpress different proteins in the thymic epithelium of these mice, either alone or in combination, in order to identify which components allow reconstitution of a permissive microenvironment. The study led to the identification of the hierarchical role of Ccl25, Cxcl12, Scf and the Notch ligand D114 in the specification of each of the lymphocytic populations in the niche. This elegant approach could be also applied to the study of stem cell niches.

\section{Future Perspectives - (Long) Way to Go}

In the last few years we have made considerable progress in our understanding of adult stem cells and their organization in specific microenvironments. The concept of a perivascular stem 
cell niche was unveiled in the bone marrow and then confirmed in other tissues (although noticeably not in all). Despite this effort, most of our knowledge of the niche is fundamentally descriptive and we still have a long way to go before tasting the fruits of regenerative bioengineering. For instance, we still lack specific markers for some of the stem cell populations, like MSCs, that will allow us to determine the contribution of these cells to tissue homeostasis. Proper markers would facilitate fate mapping studies to determine whether some or all of the perivascular stem cells share a common origin. Alternative splicing and proteomic analysis may help find new markers that specifically identify distinct stem cell populations. Importantly, factors mediating regulation of stem cells by blood vessels have only partially been unveiled (Table 1). Our ignorance of these factors may be hampering further progress in stem cell therapy, which might fuel the increasing disappointment sensed in the part of the scientific community and the society in general with this therapeutic approach.

Besides these issues, the role of the vascular stem cell niche itself in tissue homeostasis needs to be properly addressed. We need to understand the contribution of perivascular stem cells and the vessels themselves to tissue renewal and whether their interaction is necessary for the response to injury. Similarly, the biological - and therapeutical - relevance of the niche organization and structure needs to be evaluated. Biological deconstruction and bioartificial reconstruction of the stem cell microenvironment will help define the role of each of the niche components. In particular, we need to understand the precise role of blood vessels in the niche beyond their carrier function. Although many adult stem cells are localized around blood vessels in their niches, others aren't. It will be necessary to investigate why the proximity of the vasculature is dispensable for some stem cells whereas others need to be in close contact with it.

Finally, although we partially understand how the stem cell niche responds to tissue injury, its role in repair, regeneration and disease in general needs further investigation. Combination of these results with the improvement of bioartifical niches will contribute to the advancement of stem cell therapy through more complex, structured and clinically-relevant therapeutic products that will finally place us in a position to translate this knowledge into efficient clinical therapies in the future. 


\section{BIBLIOGRAPHY}

1. Yin T, Li L (2006) The stem cell niches in bone. J Clin Invest 116:1195-1201.

2. Yoshida S, Sukeno M, Nabeshima Y (2007) A vasculature-associated niche for undifferentiated spermatogonia in the mouse testis. Science 317:1722-1726.

3. Christov C, Chrétien F, Abou-Khalil R, Bassez G, Vallet G, Authier FJ, Bassaglia Y, Shinin V et al (2007) Muscle satellite cells and endothelial cells: close neighbors and privileged partners. Mol Cell Biol 18:1397-1409.

4. Tang W, Zeve D, Suh JM, Bosnakovski D, Kyba M, Hammer RE, Tallquist MD, Graff JM (2008) White fat progenitor cells reside in the adipose vasculature. Science 322:583-586.

5. Gilbertson RJ, Rich JN (2007) Making a tumour's bed: glioblastoma stem cells and the vascular niche. Nat Rev Cancer 7:733-736.

6. Armulik A, Genové G, Betsholtz C (2011) Pericytes: Developmental, Physiological, and Pathological Perspectives, Problems, and Promises. Dev Cell 21:193-215.

7. Zymek P, Bujak M, Chatila K, Cieslak A, Thakker G, Entman ML, Frangogiannis NG (2006) The role of platelet-derived growth factor signaling in healing myocardial infarcts. J Am Coll Cardiol 48:2315-2323.

8. Kim J, Wu Q, Zhang Y, Wiens KM, Huang Y, Rubin N, Shimada H, Handin RI et al (2010) PDGF signaling is required for epicardial function and blood vessel formation in regenerating zebrafish hearts. Proc Natl Acad Sci USA 107:17206-17210.

9. Crisan M, Yap S, Casteilla L, Chen C-W, Corselli M, Park TS, Andriolo G, Sun B et al (2008) A perivascular origin for mesenchymal stem cells in multiple human organs. Cell Stem Cell 3:301-313.

10. Dellavalle A, Sampaolesi M, Tonlorenzi R, Tagliafico E, Sacchetti B, Perani L, Innocenzi A, Galvez BG et al (2007) Pericytes of human skeletal muscle are myogenic precursors distinct from satellite cells. Nat Cell Biol 9:255-267.

11. Corselli M, Chen C-W, Crisan M, Lazzari L, Péault B (2010) Perivascular ancestors of adult multipotent stem cells. Arterioscler Thromb Vasc Biol 30:1104-1109.

12. Nombela-Arrieta C, Ritz J, Silberstein LE (2011) The elusive nature and function of mesenchymal stem cells. Nat Rev Mol Cell Biol 12:126-131.

13. Friedenstein A, Chailakhjan R, Lalykina K (1970) The development of fibroblast colonies in monolayer cultures of guinea-pig bone marrow and spleen cells. Cell Tissue Kinet 3:393-403.

14. Shi S, Gronthos S (2003) Perivascular niche of postnatal mesenchymal stem cells in human bone marrow and dental pulp. J Bone Miner Res 18:696-704. 
15. Mendez-Ferrer S, Michurina TV, Ferraro F, Mazloom AR, Macarthur BD, Lira SA, Scadden DT, Ma'ayan A et al (2010) Mesenchymal and haematopoietic stem cells form a unique bone marrow niche. Nature 466:829-834.

16. Schächinger V, Erbs S, Elsässer A, Haberbosch W, Hambrecht R, Hölschermann H, Yu J, Corti $\mathrm{R}$ et al (2006) Intracoronary bone marrow-derived progenitor cells in acute myocardial infarction. N Engl J Med 355:1210-1221.

17. Fernández-Avilés F, Román JaS, García-Frade J, Fernández ME, Peñarrubia MJ, Fuente LDL, Gómez-Bueno M, Cantalapiedra A et al (2004) Experimental and clinical regenerative capability of human bone marrow cells after myocardial infarction. Circ Res 95:742-748.

18. Williams AR, Trachtenberg B, Velazquez DL, Mcniece I, Altman P, Rouy D, Mendizabal AM, Pattany PM et al (2011) Intramyocardial stem cell injection in patients with ischemic cardiomyopathy: functional recovery and reverse remodeling. Circulation Research 108:792-796.

19. Hare JM, Traverse JH, Henry TD, Dib N, Strumpf RK, Schulman SP, Gerstenblith G, Demaria AN et al (2009) A randomized, double-blind, placebo-controlled, dose-escalation study of intravenous adult human mesenchymal stem cells (prochymal) after acute myocardial infarction. J Am Coll Cardiol 54:2277-2286.

20. Williams AR, Hare JM (2011) Mesenchymal stem cells: biology, pathophysiology, translational findings, and therapeutic implications for cardiac disease. Circulation Research 109:923-940.

21. Toma C, Pittenger MF, Cahill KS, Byrne BJ, Kessler PD (2002) Human mesenchymal stem cells differentiate to a cardiomyocyte phenotype in the adult murine heart. Circulation 105:93-98.

22. Quevedo HC, Hatzistergos KE, Oskouei BN, Feigenbaum GS, Rodriguez JE, Valdes D, Pattany PM, Zambrano JP et al (2009) Allogeneic mesenchymal stem cells restore cardiac function in chronic ischemic cardiomyopathy via trilineage differentiating capacity. Proc Natl Acad Sci USA 106:14022-14027.

23. Uccelli A, Moretta L, Pistoia V (2008) Mesenchymal stem cells in health and disease. Nat Rev Immunol 8:726-736.

24. Majesky MW, Dong XR, Hoglund V, Mahoney WM, Daum G (2011) The adventitia: a dynamic interface containing resident progenitor cells. Arterioscler Thromb Vasc Biol 31:15301539.

25. Ingram DA, Mead LE, Moore DB, Woodard W, Fenoglio A, Yoder MC (2005) Vessel wallderived endothelial cells rapidly proliferate because they contain a complete hierarchy of endothelial progenitor cells. Blood 105:2783-2786.

26. Zengin E, Chalajour F, Gehling UM, Ito WD, Treede H, Lauke H, Weil J, Reichenspurner H et al (2006) Vascular wall resident progenitor cells: a source for postnatal vasculogenesis. Development 133:1543-1551. 
27. Pasquinelli G, Tazzari PL, Vaselli C, Foroni L, Buzzi M, Storci G, Alviano F, Ricci F et al (2007) Thoracic Aortas from Multiorgan Donors Are Suitable for Obtaining Resident Angiogenic Mesenchymal Stromal Cells. Stem Cells 25:1627-1634.

28. Klein D, Weißhardt P, Kleff V, Jastrow H, Jakob HG, Ergün S (2011) Vascular WallResident CD44+ Multipotent Stem Cells Give Rise to Pericytes and Smooth Muscle Cells and Contribute to New Vessel Maturation. PLoS ONE 6:e20540.

29. Corselli M, Chen CW, Sun B, Yap S, Rubin JP, Péault B (2011) The tunica adventitia of human arteries and veins as a source of mesenchymal stem cells. Stem Cells Dev Epub ahead of print.

30. Invernici G, Emanueli C, Madeddu P, Cristini S, Gadau S, Benetti A, Ciusani E, Stassi G et al (2007) Human fetal aorta contains vascular progenitor cells capable of inducing vasculogenesis, angiogenesis, and myogenesis in vitro and in a murine model of peripheral ischemia. Am J Pathol 170:1879-1892.

31. Campagnolo P, Cesselli D, Al Haj Zen A, Beltrami AP, Kränkel N, Katare R, Angelini G, Emanueli $C$ et al (2010) Human adult vena saphena contains perivascular progenitor cells endowed with clonogenic and proangiogenic potential. Circulation 121:1735-1745.

32. Katare R, Riu F, Mitchell K, Gubernator M, Campagnolo P, Cui Y, Fortunato O, Avolio E et al (2011) Transplantation of human pericyte progenitor cells improves the repair of infarcted heart through activation of an angiogenic program involving micro-RNA-132. Circ Res 109:894906.

33. Passman JN, Dong XR, Wu S-P, Maguire CT, Hogan KA, Bautch VL, Majesky MW (2008) A sonic hedgehog signaling domain in the arterial adventitia supports resident Sca1+ smooth muscle progenitor cells. Proc Natl Acad Sci USA 105:9349-9354.

34. Hu Y, Zhang Z, Torsney E, Afzal AR, Davison F, Metzler B, Xu Q (2004) Abundant progenitor cells in the adventitia contribute to atherosclerosis of vein grafts in ApoE-deficient mice. J Clin Invest 113:1258-1265.

35. Psaltis PJ, Harbuzariu A, Delacroix S, Witt TA, Holroyd EW, Spoon DB, Hoffman SJ, Pan S et al (2012) Identification of a Monocyte-Predisposed Hierarchy of Hematopoietic Progenitor Cells in the Adventitia of Postnatal Murine Aorta / Clinical Perspective. Circulation 125:592603.

36. Coskun S, Hirschi KK (2010) Establishment and regulation of the HSC niche: Roles of osteoblastic and vascular compartments. Birth Defects Res C Embryo Today 90:229-242.

37. Bautch VL (2011) Stem cells and the vasculature. Nat Med 17:1437-1443.

38. Kissa K, Herbomel P (2010) Blood stem cells emerge from aortic endothelium by a novel type of cell transition. Nature 464:112-115. 
39. Bertrand JY, Chi NC, Santoso B, Teng S, Stainier DYR, Traver D (2010) Haematopoietic stem cells derive directly from aortic endothelium during development. Nature 464:108-111.

40. Boisset J-C, Van Cappellen W, Andrieu-Soler C, Galjart N, Dzierzak E, Robin C (2010) In vivo imaging of haematopoietic cells emerging from the mouse aortic endothelium. Nature 464:116-120.

41. Kiel MJ, Yilmaz ÖH, Iwashita T, Yilmaz OH, Tehorst C, Morrison SJ (2005) SLAM family receptors distinguish resource hematopoietic stem and progenitor cells and reveal endothelial niches for stem cells. Cell 121:1109-1121.

42. Arai F, Hirao A, Ohmura M, Sato H, Matsuoka S, Takubo K, Ito K, Koh GY et al (2004) Tie2/angiopoietin-1 signaling regulates hematopoietic stem cell quiescence in the bone marrow niche. Cell 118:149-161.

43. Kiel MJ, Yilmaz OH, Iwashita T, Terhorst C, Morrison SJ (2005) SLAM family receptors distinguish hematopoietic stem and progenitor cells and reveal endothelial niches for stem cells. Cell 121:1109-1121.

44. Kiel MJ, Morrison SJ (2008) Uncertainty in the niches that maintain haematopoietic stem cells. Nat Rev Immunol 8:290-301.

45. Rhodes KE, Gekas C, Wang Y, Lux CT, Francis CS, Chan DN, Conway S, Orkin SH et al (2008) The emergence of hematopoietic stem cells is initiated in the placental vasculature in the absence of circulation. Cell Stem Cell 2:252-263.

46. Chute JP, Saini AA, Chute DJ, Wells MR, Clark WB, Harlan DM, Park J, Stull MK et al (2002) Ex vivo culture with human brain endothelial cells increases the SCID-repopulating capacity of adult human bone marrow. Blood 100:4433-4439.

47. Li W, Johnson SA, Shelley WC, Yoder MC (2004) Hematopoietic stem cell repopulating ability can be maintained in vitro by some primary endothelial cells. Exp Hematol 32:1226-1237.

48. Butler JM, Nolan DJ, Vertes EL, Varnum-Finney B, Kobayashi H, Hooper AT, Seandel M, Shido K et al (2010) Endothelial cells are essential for the self-renewal and repopulation of Notch-dependent hematopoietic stem cells. Cell Stem Cell 6:251-264.

49. Duncan AW, Rattis FM, Dimascio LN, Congdon KL, Pazianos G, Zhao C, Yoon K, Cook JM et al (2005) Integration of Notch and Wnt signaling in hematopoietic stem cell maintenance. Nat Immunol 6:314-322.

50. Reya T, Duncan AW, Ailles L, Domen J, Scherer DC, Willert K, Hintz L, Nusse R et al (2003) A role for Wnt signalling in self-renewal of haematopoietic stem cells. Nature 423:409414. 
51. Varnum-Finney B, Halasz LM, Sun M, Gridley T, Radtke F, Bernstein ID (2011) Notch2 governs the rate of generation of mouse long- and short-term repopulating stem cells. J Clin Invest 121:1207-1216.

52. Calvi LM, Adams GB, Weibrecht KW, Weber JM, Olson DP, Knight MC, Martin RP, Schipani E et al (2003) Osteoblastic cells regulate the haematopoietic stem cell niche. Nature 425:841-846.

53. Zhang J, Niu C, Ye L, Huang H, He X, Tong WG, Ross J, Haug J et al (2003) Identification of the haematopoietic stem cell niche and control of the niche size. Nature 425:836-841.

54. Kiel MJ, Acar M, Radice GL, Morrison SJ (2009) Hematopoietic stem cells do not depend on N-cadherin to regulate their maintenance. Cell Stem Cell 4:170-179.

55. Kobayashi H, Butler JM, O'donnell R, Kobayashi M, Ding B-S, Bonner B, Chiu VK, Nolan DJ et al (2010) Angiocrine factors from Akt-activated endothelial cells balance self-renewal and differentiation of haematopoietic stem cells. Nat Cell Biol 12:1046-1056.

56. Oikawa A, Siragusa M, Quaini F, Mangialardi G, Katare RG, Caporali A, Van Buul JD, Van Alphen FPJ et al (2010) Diabetes mellitus induces bone marrow microangiopathy. Arterioscler Thromb Vasc Biol 30:498-508.

57. Sacchetti B, Funari A, Michienzi S, Cesare SD, Piersanti S, Saggio I, Tagliafico E, Ferrari S et al (2007) Self-renewing osteoprogenitors in bone marrow sinusoids can organize a hematopoietic microenvironment. Cell 131:324-336.

58. Sugiyama T, Kohara H, Noda M, Nagasawa T (2006) Maintenance of the hematopoietic stem cell pool by CXCL12-CXCR4 chemokine signaling in bone marrow stromal cell niches. Immunity 25:977-988.

59. Sipkins DA, Wei X, Wu JW, Runnels JM, Cote D, Means TK, Luster AD, Scadden DT et al (2005) In vivo imaging of specialized bone marrow endothelial microdomains for tumour engraftment. Nature 435:969-973.

60. Ponomaryov T, Peled A, Petit I, Taichman RS, Habler L, Sandbank J, Arenzana-Seisdedos F, Magerus A et al (2000) Induction of the chemokine stromal-derived factor-1 following DNA damage improves human stem cell function. J Clin Invest 106:1331-1339.

61. Ferraro F, Lymperi S, Méndez-Ferrer S, Saez B, Spencer JA, Yeap BY, Masselli E, Graiani $\mathrm{G}$ et al (2011) Diabetes impairs hematopoietic stem cell mobilization by altering niche function. Sci Transl Med 3:104ra101.

62. Schajnovitz A, Itkin T, D'uva G, Kalinkovich A, Golan K, Ludin A, Cohen D, Shulman Z et al (2011) CXCL12 secretion by bone marrow stromal cells is dependent on cell contact and mediated by connexin-43 and connexin-45 gap junctions. Nat Immunol 12:391-398. 
63. Avecilla ST, Hattori K, Heissig B, Tejada R, Liao F, Shido K, Jin DK, Dias S et al (2004) Chemokine-mediated interaction of hematopoietic progenitors with the bone marrow vascular niche is required for thrombopoiesis. Nat Med 10:64-71.

64. Chow A, Lucas D, Hidalgo A, Méndez-Ferrer S, Hashimoto D, Scheiermann C, Battista M, Leboeuf $\mathrm{M}$ et al (2011) Bone marrow CD169+ macrophages promote the retention of hematopoietic stem and progenitor cells in the mesenchymal stem cell niche. J Exp Med 208:261-271.

65. Christopher MJ, Rao M, Liu F, Woloszynek JR, Link DC (2011) Expression of the G-CSF receptor in monocytic cells is sufficient to mediate hematopoietic progenitor mobilization by GCSF in mice. J Exp Med 208:251-260.

66. Ding L, Saunders TL, Enikolopov G, Morrison SJ (2012) Endothelial and perivascular cells maintain haematopoietic stem cells. Nature 481:457-462.

67. Doe CQ (2008) Neural stem cells: balancing self-renewal with differentiation. Development 135:1575-1587.

68. Doetsch F (2003) A niche for adult neural stem cells. Curr Op Genet Dev 13:534-550.

69. Moore KA, Lemischka IR (2006) Stem cells and their niches. Science 311:1880-1885.

70. Goldman SA, Chen Z (2011) Perivascular instruction of cell genesis and fate in the adult brain. Nat Neurosci 14:1382-1389.

71. Palmer TD, Willhoite AR, Gage FH (2000) Vascular niche for adult hippocampal neurogenesis. J Comp Neurol 425:479-494.

72. Tavazoie M, Veken LVD, Silva-Vargas V, Louissaint M, Colonna L, Zaidi B, GarciaVerdugo JM, Doetsch F (2008) A specialized vascular niche for adult neural stem cells. Cell Stem Cell 3:279-288.

73. Shen Q, Wang Y, Kokovay E, Lin G, Chuang SM, Goderie SK, Roysam B, Temple S (2008) Adult SVZ stem cells lie in a vascular niche: a quantitative analysis of niche cell-cell interactions. Cell Stem Cell 3:289-300.

74. Kokovay E, Goderie S, Wang Y, Lotz S, Lin G, Sun Y, Roysam B, Shen Q et al (2010) Adult SVZ lineage cells home to and leave the vascular niche via differential responses to SDF1/CXCR4 signaling. Cell Stem Cell 7:163-173.

75. Shen Q, Goderie SK, Jin L, Karanth N, Sun Y, Abramova N, Vincent P, Pumiglia K et al (2004) Endothelial cells stimulate self-renewal and expand neurogenesis of neural stem cells. Science 304:1338-1340.

76. Ramírez-Castillejo C, Sánchez-Sánchez F, Andreu-Agulló C, Ferrón SR, Aroca-Aguilar JD, Sánchez P, Mira H, Escribano J et al (2006) Pigment epithelium-derived factor is a niche signal for neural stem cell renewal. Nat Neurosci 9:331-339. 
77. Andreu-Agullo C, Morante-Redolat JM, Delgado AC, Farinas I (2009) Vascular niche factor PEDF modulates Notch-dependent stemness in the adult subependymal zone. Nat Neurosci 12:1514-1523.

78. Eyler Christine e, Wu Q, Yan K, Macswords Jennifer m, Chandler-Militello D, Misuraca Katherine 1, Lathia Justin d, Forrester Michael t et al (2011) Glioma stem cell proliferation and tumor growth are promoted by nitric oxide synthase-2. Cell 146:53-66.

79. Dunbar AJ, Goddard C (2000) Structure-function and biological role of betacellulin. Int J Biochem Cell Biol 32:805-815.

80. Gómez-Gaviro MV, Scott CE, Sesay AK, Matheu A, Booth S, Galichet C, Lovell-Badge R (2012) Betacellulin promotes cell proliferation in the neural stem cell niche and stimulates neurogenesis. Proc Natl Acad Sci USA 109:1317-1322.

81. Leventhal C, Rafii S, Rafii D, Shahar A, Goldman SA (1999) Endothelial trophic support of neuronal production and recruitment from the adult mammalian subependyma. Mol Cell Neurosci 13:450-464.

82. Louissaint Jr A, Rao S, Leventhal C, Goldman SA (2002) Coordinated interaction of neurogenesis and angiogenesis in the adult songbird brain. Neuron 34:945-960.

83. Bergmann O, Bhardwaj RD, Bernard S, Zdunek S, Barnabé-Heider F, Walsh S, Zupicich J, Alkass K et al (2009) Evidence for cardiomyocyte renewal in humans. Science 324:98-102.

84. Leri A, Kajstura J, Anversa P (2011) Role of cardiac stem cells in cardiac pathophysiology: a paradigm shift in human myocardial biology. Circ Res 109:941-961.

85. Chong James jH, Chandrakanthan V, Xaymardan M, Asli Naisana s, Li J, Ahmed I, Heffernan C, Menon Mary k et al (2011) Adult cardiac-resident MSC-like stem cells with a proepicardial origin. Cell Stem Cell 9:527-540.

86. Galvez BG, Sampaolesi M, Barbuti A, Crespi A, Covarello D, Brunelli S, Dellavalle A, Crippa $S$ et al (2008) Cardiac mesoangioblasts are committed, self-renewable progenitors, associated with small vessels of juvenile mouse ventricle. Cell Death Differ 15:1417-1428.

87. Bearzi C, Leri A, Lo Monaco F, Rota M, Gonzalez A, Hosoda T, Pepe M, Qanud K et al (2009) Identification of a coronary vascular progenitor cell in the human heart. Proc Natl Acad Sci USA 106:15885-15890.

88. Dellavalle A, Maroli G, Covarello D, Azzoni E, Innocenzi A, Perani L, Antonini S, Sambasivan R et al (2011) Pericytes resident in postnatal skeletal muscle differentiate into muscle fibres and generate satellite cells. Nat Commun 2:499.

89. Dar A, Domev H, Ben-Yosef O, Tzukerman M, Zeevi-Levin N, Novak A, Germanguz I, Amit M et al (2012) Multipotent vasculogenic pericytes from human pluripotent stem cells promote recovery of murine ischemic limb / clinical perspective. Circulation 125:87-99. 
90. Sampaolesi M, Torrente Y, Innocenzi A, Tonlorenzi R, D’antona G, Pellegrino MA, Barresi $\mathrm{R}$, Bresolin N et al (2003) Cell therapy of a-sarcoglycan null dystrophic mice through intraarterial delivery of mesoangioblasts. Science 301:487-492.

91. De Angelis L, Berghella L, Coletta M, Lattanzi L, Zanchi M, Gabriella M, Ponzetto C, Cossu G (1999) Skeletal myogenic progenitors originating from embryonic dorsal aorta coexpress endothelial and myogenic markers and contribute to postnatal muscle growth and regeneration. $\mathrm{J}$ Cell Biol 147:869-878.

92. Sampaolesi M, Blot S, D'antona G, Granger N, Tonlorenzi R, Innocenzi A, Mognol P, Thibaud JL et al (2006) Mesoangioblast stem cells ameliorate muscle function in dystrophic dogs. Nature 444:574-579.

93. Qu-Petersen Z, Deasy B, Jankowski R, Ikezawa M, Cummins J, Pruchnic R, Mytinger J, Cao $\mathrm{B}$ et al (2002) Identification of a novel population of muscle stem cells in mice. J Cell Biol 157:851-864.

94. Okada M, Payne TR, Zheng B, Oshima H, Momoi N, Tobita K, Keller BB, Phillippi JA et al (2008) Myogenic endothelial cells purified from human skeletal muscle improve cardiac function after transplantation into infarcted myocardium. J Am Coll Cardiol 52:1869-1880.

95. Valina C, Pinkernell K, Song Y-H, Bai X, Sadat S, Campeau RJ, Le Jemtel TH, Alt E (2007) Intracoronary administration of autologous adipose tissue-derived stem cells improves left ventricular function, perfusion, and remodelling after acute myocardial infarction. Eur Heart $\mathbf{J}$ 28:2667-2677.

96. Houtgraaf JH, Den Dekker WK, Van Dalen BM, Springeling T, De Jong R, Van Geuns RJ, Geleijnse ML, Fernandez-Aviles F et al (2012) First experience in humans using adipose tissuederived regenerative cells in the treatment of patients with ST-segment elevation myocardial infarction. J Am Coll Cardiol 59:539-540.

97. Rodeheffer MS, Birsoy K, Friedman JM (2008) Identification of white adipocyte progenitor cells in vivo. Cell 135:240-249.

98. Festa E, Fretz J, Berry R, Schmidt B, Rodeheffer M, Horowitz M, Horsley V (2011) Adipocyte lineage cells contribute to the skin stem cell niche to drive hair cycling. Cell 146:761 771.

99. Majka SM, Fox KE, Psilas JC, Helm KM, Childs CR, Acosta AS, Janssen RC, Friedman JE et al (2010) De novo generation of white adipocytes from the myeloid lineage via mesenchymal intermediates is age, adipose depot, and gender specific. Proc Natl Acad Sci USA 107:1478114786.

100. Zeve D, Tang W, Graff J (2009) Fighting fat with fat: the expanding field of adipose stem cells. Cell Stem Cell 5:472-481. 
101. Kolonin MG, Saha PK, Chan L, Pasqualini R, Arap W (2004) Reversal of obesity by targeted ablation of adipose tissue. Nat Med 10:625-632.

102. Cao Y (2010) Adipose tissue angiogenesis as a therapeutic target for obesity and metabolic diseases. Nat Rev Drug Discov 9:107-115.

103. Traktuev DO, Prater DN, Merfeld-Clauss S, Sanjeevaiah AR, Saadatzadeh MR, Murphy M, Johnstone BH, Ingram DA et al (2009) Robust functional vascular network formation in vivo by cooperation of adipose progenitor and endothelial cells. Circ Res 104:1410-1420.

104. Davidoff MS, Middendorff R, Enikolopov G, Riethmacher D, Holstein AF, Müller D (2004) Progenitor cells of the testosterone-producing Leydig cells revealed. J Cell Biol 167:935944.

105. Oatley JM, Oatley MJ, Avarbock MR, Tobias JW, Brinster RL (2009) Colony stimulating factor 1 is an extrinsic stimulator of mouse spermatogonial stem cell self-renewal. Development 136:1191-1199.

106. Peerani R, Zandstra PW (2010) Enabling stem cell therapies through synthetic stem cellniche engineering. J Clin Invest 120:60-70.

107. Nakano-Doi A, Nakagomi T, Fujikawa M, Nakagomi N, Kubo S, Lu S, Yoshikawa H, Soma $\mathrm{T}$ et al (2010) Bone marrow mononuclear cells promote proliferation of endogenous neural stem cells through vascular niches after cerebral infarction. Stem Cells 28:1292-1302.

108. Nakagomi N, Nakagomi T, Kubo S, Nakano-Doi A, Saino O, Takata M, Yoshikawa H, Stern DM et al (2009) Endothelial cells support survival, proliferation, and neuronal differentiation of transplanted adult ischemia-induced neural stem/progenitor cells after cerebral infarction. Stem Cells 27:2185-2195.

109. Engler AJ, Sen S, Sweeney HL, Discher DE (2006) Matrix elasticity directs stem cell lineage specification. Cell 126:677-689.

110. Suda T, Takubo K, Semenza Gregg 1 (2011) Metabolic regulation of hematopoietic stem cells in the hypoxic niche. Cell Stem Cell 9:298-310.

111. Vunjak-Novakovic G, Scadden David t (2011) Biomimetic platforms for human stem cell research. Cell Stem Cell 8:252-261.

112. Gobaa S, Hoehnel S, Roccio M, Negro A, Kobel S, Lutolf MP (2011) Artificial niche microarrays for probing single stem cell fate in high throughput. Nat Meth 8:949-955.

113. Calderón L, Boehm T (2012) Synergistic, context-dependent, and hierarchical functions of epithelial components in thymic microenvironments. Cell 149:159-172. 


\section{CLINICAL STATEMENT}

Full characterization of the stem cell niche is needed in order to identify the cues that direct their differentiation and self-renewal. Understanding the microenvironmental factors that regulate stem cell behaviour and in particular those supplied by the endothelium will allow the generation of more efficient cell therapies, moving from stem cell injection to more complex treatments based on bioartificial stem cell niches. 


\section{FIGURE LEGENDS}

Figure 1. Adult stem cells are often located in the proximity of blood vessels in their niche. A, Hematopoietic stem cells (HSCs) and mesenchymal stem cells (MSCs) in the bone marrow are close to blood vessels, which secrete SDF-1, SCF, PDGF- $\beta$ and Wnt to regulate their function. B, In the adult brain, neural stem cells (NSCs) are adjacent or in the vicinity of capillaries that regulate their behaviour by secreting BTC and PEDF. BV, blood vessel; LV, lateral ventricle; (B) NSCs; (C) transit-amplifying cells; (A) neuroblasts. C, A population of MSC-like cells and other progenitor cells reside close to blood vessels in the heart. The factors secreted by the vasculature to regulate these cells have not been unveiled yet.

Figure 2. Neural stem cells are located close to blood vessels in the adult brain. Adult mouse brains were isolated, fixed and stained with antibodies directed against markers for different cell populations. NSCs were identified by strong expression of SOX2 (blue) and transit-amplifying progenitors were labelled with anti-Mash1 (red). Blood vessels were stained with anti-CD31 (green). A higher magnification is shown in the right panel. LV, left ventricle; RMS, rostral migratory stream. Bar, $100 \mu \mathrm{m}$.

Figure 3. The adipose stem cell niche. In white fat tissue, $\mathrm{Sca} 1^{+} / \mathrm{CD} 34^{+}$adipose stem cells (ASC) are localized around blood vessels among other mural cells. ASCs can respond to high fat diet and generate new adipocytes. In contrast, mesenchymal stem cells (MSC) have a wider differentiation capacity that makes them good candidates for stem cell therapies of different diseases, including myocardial infarction. Blood vessels regulate ASCs through an unknown mechanism and conversely adipose progenitors can promote vessel formation by secreting VEGF and other angiogenic factors. 


\section{Figure 4. Integration of different regulatory stimuli into bioartificial stem cell niches.}

Artificial stem cell niches must integrate biochemical and biomechanical cues that reproduce the environment faced by stem cells in the niche. The bioartificial niche must obviously include multipotent stem cells capable of generating adult differentiated tissue. It should also contain support cells that provide the necessary signals for stem cell regulation. Part of these regulatory cues must be provided by blood vessels, although they could be substituted by proteinconjugated microbeads or by attaching cell surface ligands to the scaffold surface. Structural support in the form of matrices or hydrogels will not only provide a scaffold for the cells but will also allow localized delivery of growth factors. Importantly, artificial niches must also incorporate mechanical cues and should be engineered in such a way that they deliver the right amount of oxygen to stem cells. 


\begin{tabular}{|c|c|c|c|}
\hline $\begin{array}{l}\text { Growth } \\
\text { Factor }\end{array}$ & $\begin{array}{l}\text { Stem Cell } \\
\text { Niche }\end{array}$ & Activity in the Niche & Ref. \\
\hline PDGF- $\beta$ & Mesenchymal & Regulates pericyte-endothelial cell communication & 6 \\
\hline SDF-1 & HSC, Neuronal & $\begin{array}{l}\text { Recruitment of HSC and NSC to niche blood } \\
\text { vessels }\end{array}$ & 58,74 \\
\hline SCF/KITL & HSC & Maintenance of HSC in bone marrow & 66 \\
\hline Wnt & HSC & Regulates HSC self-renewal and growth & 49,50 \\
\hline $\mathrm{BDNF}$ & Neuronal & Guides migration and stimulates neurogenesis & 77,81 \\
\hline PEDF & Neuronal & Enhances PEDF self-renewal & 76,77 \\
\hline BTC & Neuronal & $\begin{array}{l}\text { Stimulates NCSs and progenitors proliferation, } \\
\text { induces neurogenesis }\end{array}$ & 80 \\
\hline FGF2 & Skeletal muscle & Stimulates satellite cell growth & 3 \\
\hline HGF & Skeletal muscle & Stimulates satellite cell growth & 3 \\
\hline IGF-1 & Skeletal muscle & Stimulates satellite cell growth & 3 \\
\hline VEGF & $\begin{array}{l}\text { Skeletal muscle, } \\
\text { neuronal }\end{array}$ & $\begin{array}{l}\text { Stimulates satellite cell growth; induces } \\
\text { neurogenesis and angiogenesis }\end{array}$ & 3,82 \\
\hline CSF-1 & Spermatogonial & Regulates spermatogonial stem cell self-renewal & 105 \\
\hline
\end{tabular}

Table 1. Soluble growth factors released by the vasculature (endothelial cells or mural cells) that regulate adult stem cells in different niches. PDGF- $\beta$, platelet-derived growth factor- $\beta$; SDF-1, stromal cell-derived factor-1; SCF, stem cell factor; BDNF, brain-derived neurotrophic factor; PEDF, pigment epithelium-derived factor; BTC, betacellulin; FGF2, fibroblast growth factor 2; HGF, hepatocyte growth factor; IGF-1, insulin-like growth factor; VEGF, vascular endothelium growth factor; CSF-1, colony stimulating factor-1. 
A

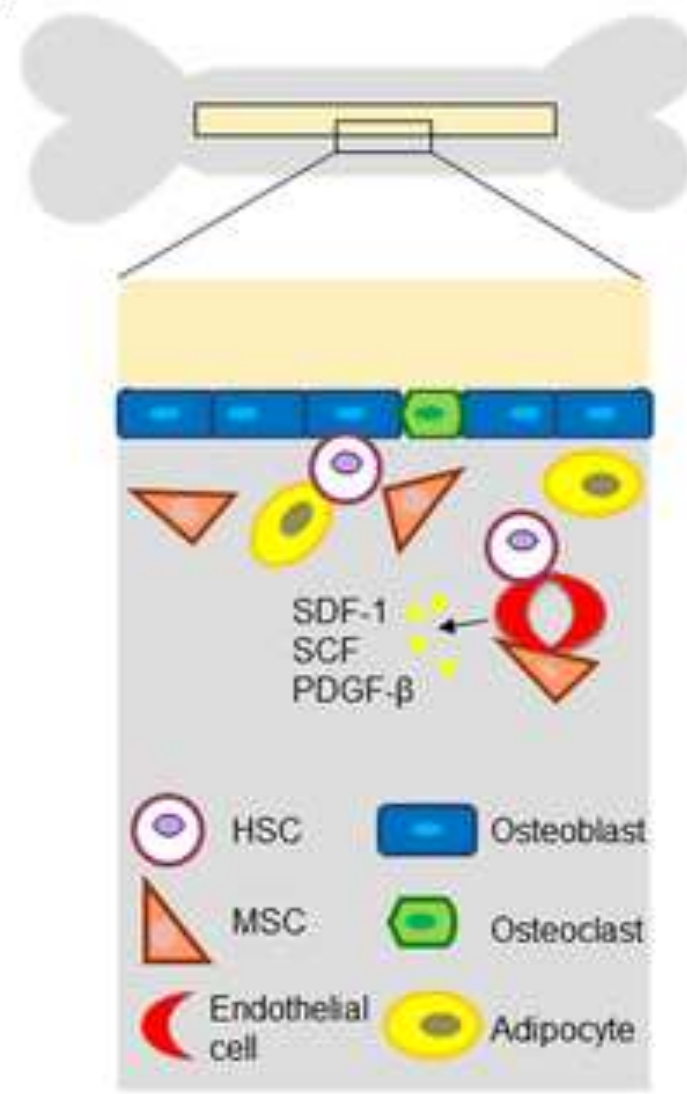

B

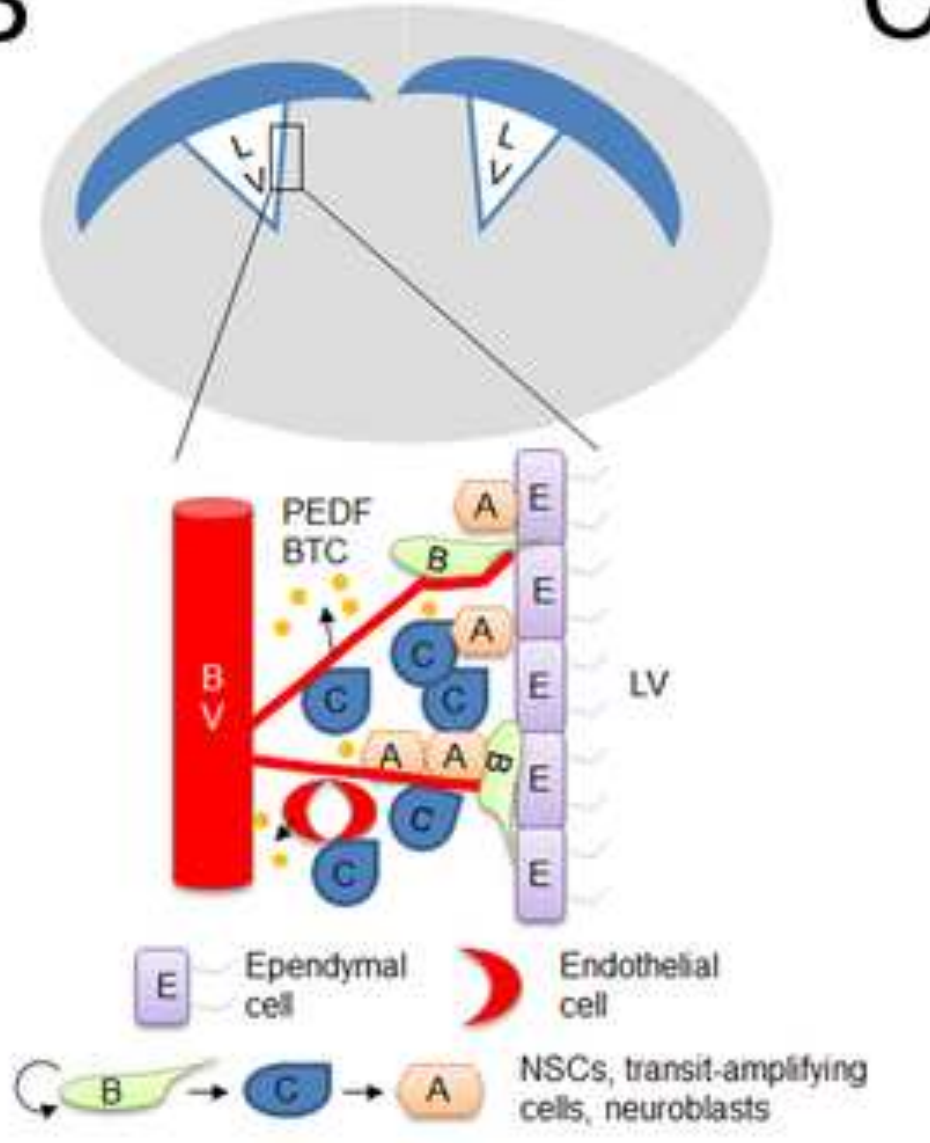

C

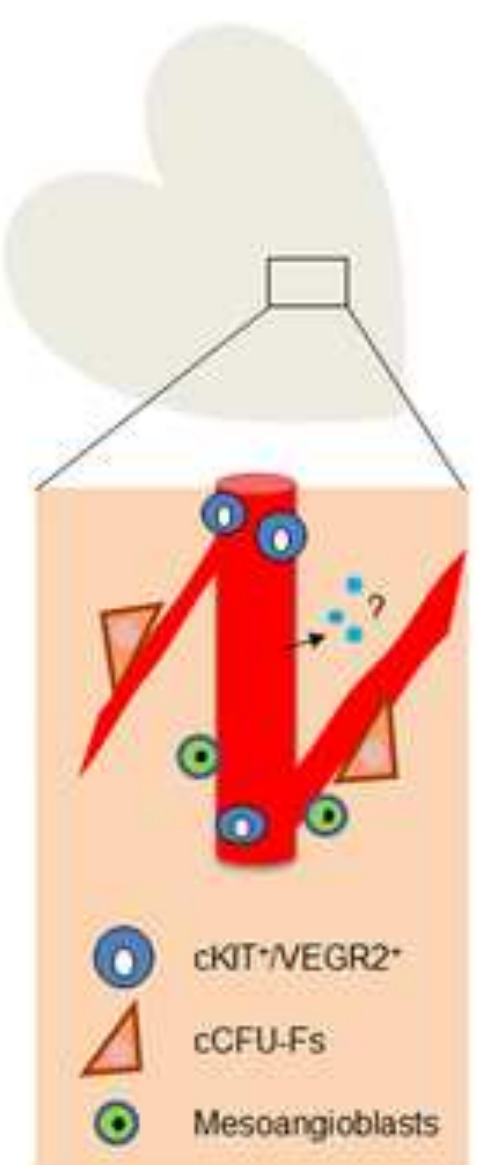

Gómez-Gaviro et al., Fig. 1 

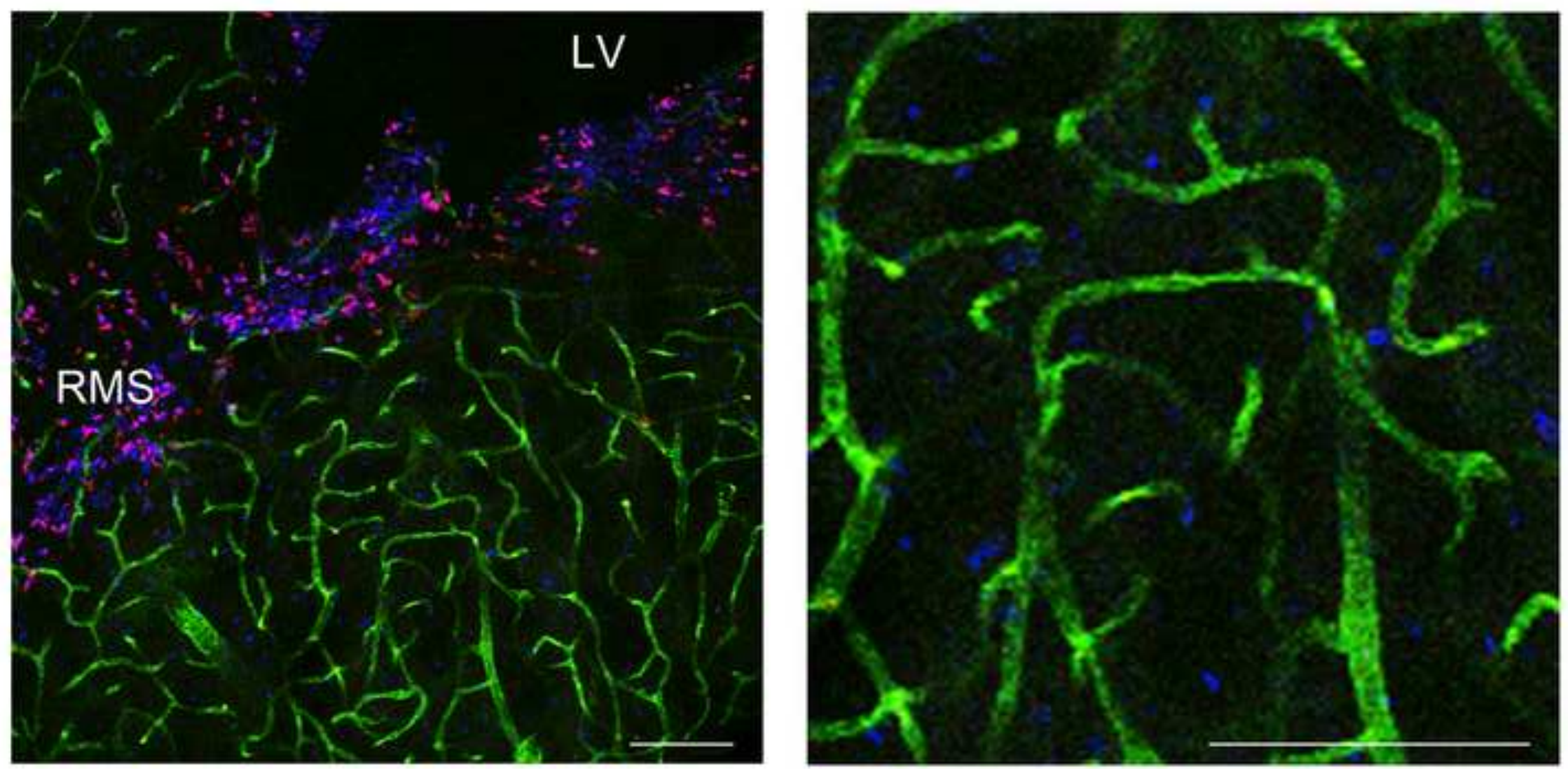

Gómez-Gaviro et al., Fig. 2 


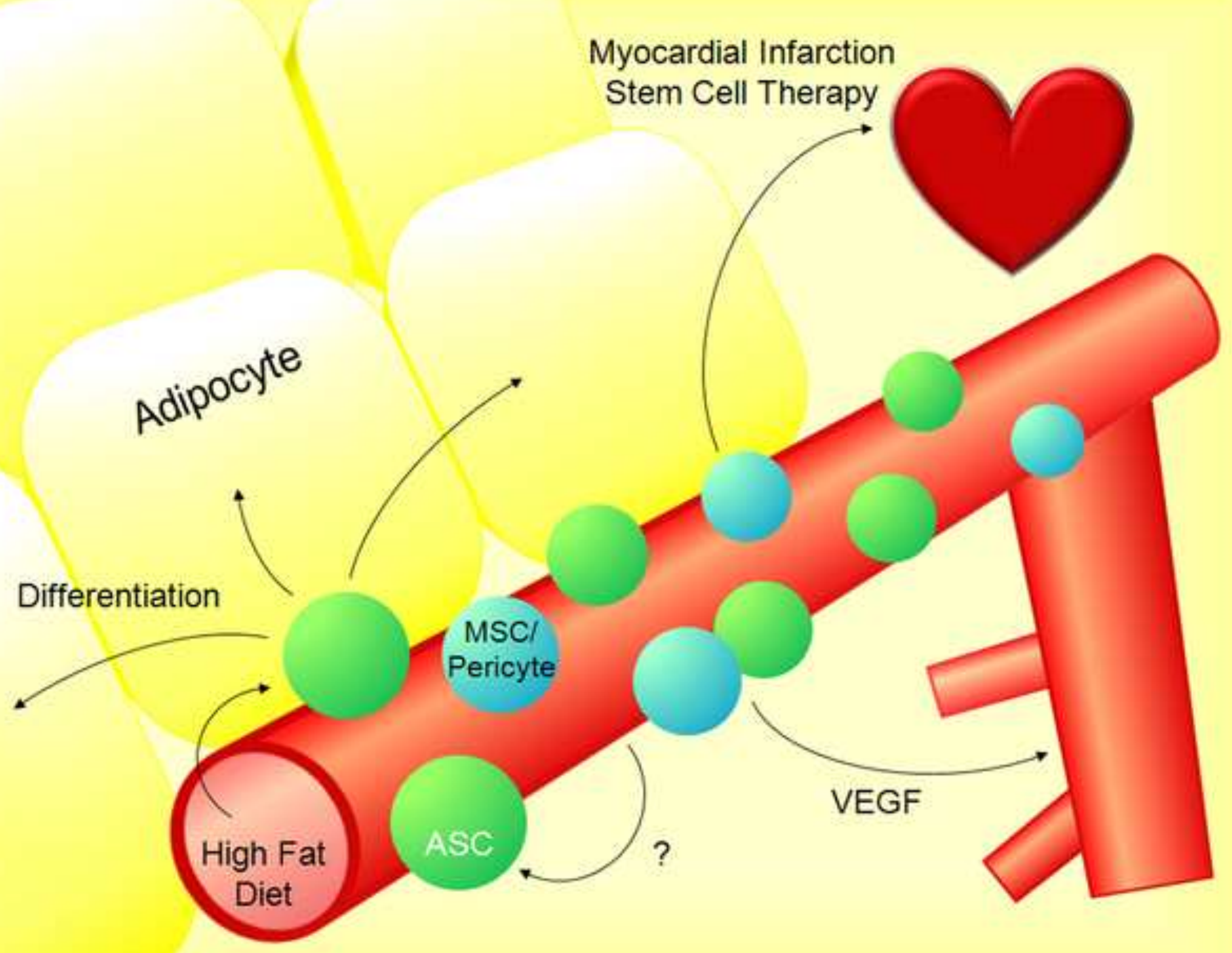

Gómez-Gaviro et al., Fig. 3 


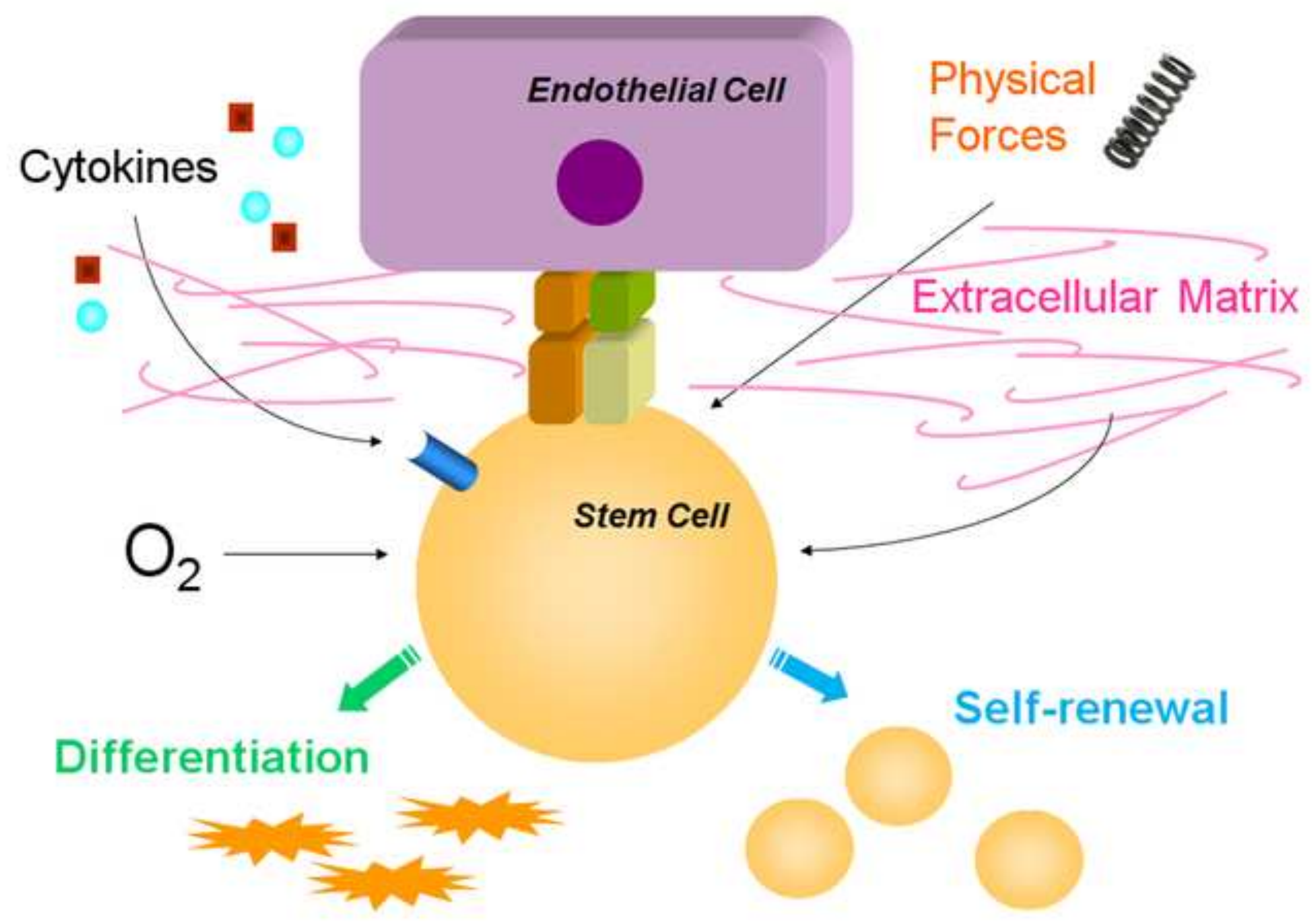

Gómez-Gaviro et al., Fig. 4 